Branko Klun

\title{
Transcendence and Acknowledgment: Questioning Marion's Reversal in Phenomenology
}

\section{Transcendenca in priznanje: Vprašanja glede Mario- novega obrata $v$ fenomenologiji}

Abstract: Marion gives a new interpretation to the phenomenological notion of givenness (of a phenomenon) by attributing to this phenomenon a "self « which is, in a certain sense, independent from and prior to its reception by the subject (as »the gifted one«, adonné). In this way, Marion pleads for a phenomenological turn which can also be described in terms of counter-intentionality and counter-method. However, this turn is not a logical necessity, but a (rationally grounded) decision which the subject, or adonné has to make. In this paper I would like to interrelate this decision to the notion of acknowledgement. The adonné, by acknowledging the priority of givenness over its own receiving capacities, adopts the attitude of humility in every relation to reality (not understood ontologically, but in its "saturated " phenomenality). This attitude is of fundamental importance with regard to (the possibility of) the phenomenon of revelation.

Key words: Phenomenology of Religion, Marion, Levinas, Transcendence, Givenness, Counter-Intentionality

Povzetek: Marion poda novo razlago fenomenološkega pojma danosti (nekega fenomena), ko fenomenu pripiše nasebnost, ki je neodvisna in predhodna sprejetju s strani subjekta (kot »obdarjenega«). Na tej osnovi zagovarja fenomenološki obrat, ki ga opiše tudi s pojmi proti-intencionalnosti in proti-metode. Toda ta obrat ni logična nujnost, temveč (razumsko utemeljena) odločitev, ki jo mora napraviti subjekt (oziroma obdarjeni). $V$ tem prispevku želim povezati to odločitev s pojmom priznanja. Ko obdarjeni prizna prioriteto danosti pred sposobnostjo lastnega sprejetja, zavzame držo ponižnosti v odnosu do resničnosti (pri čemer slednje ne gre razumeti ontološko, temveč v njeni »nasičeni« fenomenalnosti). Takšna drža je temeljnega pomena za odnos do (možnosti) fenomena razodetja.

Ključne besede: fenomenologija religije, Marion, Levinas, transcendenca, danost, proti-intencionalnost 
There is a legitimate question as to whether the "turn « of French phenomenology toward "excessive " phenomena - with its subsequent abandonment of intentional correlation as one of the pillars of classical phenomenology - is not the result of a hidden theological agenda which has invaded phenomenology, a rigorous and universal science. Are we dealing with a theological turn, coming from outside of phenomenology, as suggested in the famous critique of Janicaud (2000)? Or is this turn the result of a development within phenomenology itself, which found itself having to respond to the paradoxical givenness of various excessive or "transcendent " phenomena, and having to abandon its classical methodological presuppositions in order to be faithful to its original vocation: to allow us to see phenomena as they show themselves, in and from themselves? In the second case the proximity between phenomenology and theology would be incidental, referring mainly to the structural similarities between a passive subject and the superabundant givenness of paradoxical phenomena.

In this paper ${ }^{1}$ I argue for this latter position. From Husserl's very conception of phenomenology there has been a fundamental ambiguity concerning the phenomenological reduction. It pursues two distinct, but interrelated objectives: on one hand, it is oriented towards the "things themselves" (or to the "phenomena themselves " in Heidegger's version), where "themselves " stands precisely for the priority of phenomena over the subject which seeks to "subject " or subordinate the phenomena to its own will and domination. On the other hand, adequate phenomenological knowledge, as the final goal of the phenomenological reduction, is an act of the subject, of the consciousness, which breaks with the naïve realism that overlooks the exemption of the subject (or of the consciousness) from the world of objects. The phenomenological reduction reduces such presumed objects to their givenness to consciousness, but this process of "bringing back" to the subject nevertheless seeks to safeguard the original truth (more "objective« than the truth within a supposed objective world) of these phenomena.

There is, however, a constant tension between the two objectives. If we ascribe a horizontal structure to knowledge or to the understanding performed by consciousness (or to Dasein), then this (intentional) horizon takes on a transcendental role. It becomes the condition of possibility for any knowledge or understanding of phenomena. But how are we to come to the phenomena themselves if they can only appear within the horizon opened by the knowing subject? The need to overcome the transcendental role of the subject can be observed in the phenomenological development of Husserl (by recognizing various forms of passivity in the process of phenomenological constitution) and even more radically in the "turn " (Kehre) of Heidegger. Heidegger deposes Dasein from its central position in Being and Time and attributes to Being the priority and initiative of disclosing and giving itself. However, Being - as Levinas and Marion rightly observe - still functions as a (transcendental) horizon for the understanding (or consti-

1 This paper was written in the context of the research project The Return of the Religious in Postmodern thought as a Challenge for Theology (J6-7325), and was financially supported by the Slovenian Research Agency. 
tution) of beings (entities). The deposition of the subject in a post-foundational phenomenology does not necessarily lead to the renouncement of the transcendental approach as such.

Here precisely lies the problem for Levinas, who tries to introduce a reversal or a turn within phenomenology itself. Even if he offers several studies on passive elements in Husserl's phenomenology (ranging from sensibility and embodiment to the paradoxical nature of time consciousness), his central argument remains tied to the paradoxical phenomenon of the face, in front of which the transcendental approach experiences its most evident failure. It is true that there are other motives in Levinas' engagement with phenomenology and that his quest of transcendence has indubitable religious implications - something which may be suspicious for Janicaud. Still, Levinas seeks to remain within the methodological boundaries of phenomenology, and to challenge these implications from within.

In this paper, I will start with Levinas' »turn « within phenomenology, which he describes as an inversion of intentionality, and then proceed with Marion's turn, which introduces a methodological reversal in the very idea of the phenomenological reduction. It is evident that such a reversal, which grants the priority of otherness or givenness over that of the receiving subject, offers new possibilities of dialogue with the phenomenon of religion, which is structured in a similar way: as a priority of transcendence over the subjectivity of the self. But how can such a turn within phenomenology be justified? On which presuppositions is it based? How can an active and knowing subject end up with the conclusion that it is the passive receiver of a prior and transcendent givenness? For this purpose, I would like to introduce the component of acknowledgement. If knowledge - as a fundamental notion and the goal of any philosophical enterprise - tends to capture the object of its knowing and to reinstate the knowing subject in its transcendental role, there is also a moment of acknowledgement which is different than the act of knowing itself. The acknowledgment of a transcendent otherness, or a paradoxical givenness, comes close to the notion of decision, but it is the decision of someone who has been passively confronted with a claim from outside of the self, and who has to respond to this claim. The methodological turn which follows such an acknowledgment is not a rational necessity, as it includes the freedom of response. But let us develop the argument in close connection with Levinas und Marion.

\section{Levinas and the inversion of intentionality}

For Levinas, the face of the other (person) represents an exception among the phenomena which constitute the world, and it is even characterized as a »pure hole in the world" (Levinas 1994, 198). There is no intentionality that could adequately correlate with the face of the other, not even the intentionality of sensibility (and enjoyment) which, in Levinas' early works, is considered as prior to the theoretical intentionality of Husserl's phenomenology. However, the face 
does not remain a pure negation, or a mere deficit, because it is able to affect the subject, to ethically »manifest» it. "The face speaks", writes Levinas $(1969,198)$. When confronted with the ethical call of the other - prior to any word being spoken - the subject finds itself in the passive position of being called to responsibility prior to its own initiative and activity. It is deposed from its central and transcendental position. The primacy of the other leads to a methodological reversal which can be observed in the transition from Levinas's first major work Totality and Infinity to his second major work Autrement qu'être. The notion of the exteriority of the other is replaced and radicalized by the specific interiority (and temporal priority) of the other within the (ethical) subject itself: it is always already penetrated by the other; there is a fission within the subject (the-Other-in-the-Same). The broken ontological identity is replaced by an ethical subjectivity qua responsibility. This responsibility, writes Levinas, is »irreducible to consciousness of ..., and describable, if possible, as an inversion of intentionality« $(1991,47)$.

With the notion of »inversion« or »bouleversement« $(1994,196)$ of intentionality, Levinas tries to express the paradox of being in relation to something that (infinitely) transcends the (finite) understanding of the subject. Levinas wants to see this inversion as a methodological program: instead of starting with my consciousness and its understanding (as the obvious point of departure), I have to start from the Other, from beyond my Self. In my responsibility (in my interiority) I discover the call that preceded me in the same way that I discover (in my exteriority) that the face of the Other possesses a specific transcendence which cannot be reduced to an intentional meaning within my consciousness.

But is such an inversion or reversal of intentionality really possible? One could argue from the standpoint of classical phenomenology that intentionality refers to the very fact of understanding, and that an inversion can only be a metaphorical way of saying that my consciousness understands that it is being regarded or called by the other. There can be no »inversion of intentionality«, but only the »intentionality of inversion « (Welten 2004, 89-90). I can objectify my neighbor through the meaning-bestowal of my consciousness, or I can understand him as transcendent, as truly other and irreducible to any meaning that I may impose on him. Even in this second case we still have an understanding - it is the understanding of what we do not, or cannot, understand.

This is precisely the objection which comes to Levinas from hermeneutics. In contrast to Levinas' thesis about the violence of every understanding (to understand something implies reducing its otherness to the categories of one's own understanding), hermeneutics regards understanding as a fundamentally positive act. According to hermeneutics the only problem is that of an inadequate understanding or knowledge. The fundamental task consists in the quest for an adequate understanding - which is a way of searching for the truth. The subject always presupposes and disposes of some understanding, which creates the horizon of its openness to the world. It is within this horizon that it encounters phenomena, but it does not want to subjugate phenomena to this horizon. In the dialogical version of hermeneutics, understanding possesses a dynamic dimension, since 
the horizon of understanding is constantly modified by the interaction with phenomena, and is in a never-ending quest for more adequate knowledge (and for the truth).

Levinas, in contrast, dismisses any possibility of a hermeneutical approach to the otherness (alterity) of the other. Translated into phenomenological terms, such an approach would imply the possibility of a constant improvement of the intentional approach. It would represent the search for an adequate intentionality, which would be able to respond to the other (Klun 2012). But Levinas demands more. There can be no adequate intentionality, but only its subversive reversal. Yet how can this reversal come about? Where is the point at which the subject sacknowledges" the absolute priority of the other - or where it acknowledges an alterity beyond any knowledge?

I think this reversal is not possible without a certain decision on the part of the subject, even if Levinas strongly opposes any active element (which a decision undoubtedly entails), since he feels this would endanger the original passive status of the subject ("more passive than all passivity«, Levinas 1991, 14). And yet, I have to decide how to respond. Confronted by the call of the other - either in the physical exteriority of his face or in the interiority of my ethical subjectivity (which amounts to the same) - I find myself compelled to respond, but an essential element of my response consists in "acknowledging " the priority of the call or, according to Mensch, in "the internalization of an alternate perspective, one that can call our own into question « (Mensch 2017, 484). It is not a contradiction to think that there is no such call. A similar situation can be described in front of the face of the other. What happens when I "see« in this face - which is also a physical phenomenon - an infinite (ethical) transcendence? This is not an obvious experience, and it is not irrational to deny it. The acknowledgment of this infinite transcendence (Esterbauer 2013) is therefore not a rational necessity, but neither is it a blind decision, or a pure leap of faith. It is motivated and justified by reason. It is reasonable to assume the paradoxical view that I can never form an adequate understanding of the other and that his infinite, ethical call can never be met adequately by my finite response.

The inversion of intentionality therefore consists in an act of acknowledgement, which never achieves the status of knowledge. To know (in the sense of intentionality) would re-establish mastery and domination over what is known (intended). To acknowledge, in contrast, has the character of a response: the acknowledgement re-acts to a prior claim or call. There is, however, no correlation between the call and the response: the acknowledgement is asymmetrical and no response (as an active decision) can offset the initial passivity of the subject. It is similar to Levinas' distinction between the "saying" and the "said " (Levinas 1991, 37). No(thing) "said « can exhaust the infinite ethical vocation implied in the act of "saying". There is no new intentionality which could grasp what is meant with the inversion of intentionality. 


\section{Marion: givenness and counter-intentionality}

Marion shares Levinas' critique of Husserl and Heidegger with regard to their transcendental approach and their inability to be open to genuine transcendence. But he does not follow Levinas in his assumption of the privileged role of the other (person) and of ethics (the relation to the other) as the original place for the manifestation of transcendence. Marion does not regard the face as a hole in the world, as a lack or deficit, but rather as an excess or surplus of phenomenality. This is a very important methodological move, which allows Marion to open phenomenology to the variety of ways in which phenomena can give themselves. And, his abandonment of the phenomenological demand of correlation is equally important. For Marion, the principle of correlation is a consequence of the transcendental approach, which poses limits on how phenomena can manifest themselves. That principle attests to the priority of the intention(ality) over intuition. For Husserl, authentic and adequate knowledge (in contrast to inadequate knowledge) can only be achieved when an intention is adequately fulfilled in intuition (Anschauung), but it would make no sense for him to speak about the excess of intuition over intention. Marion disputes the priority of intention over intuition and concedes the possibility of such phenomena which "overflow" or "saturate« intention by an excess of intuition. He refers to those phenomena the face being one of them - as »saturated " phenomena.

This leads not only to phenomenology's extension to new types of phenomenality, but also to a radical transformation of phenomenology as such. The acknowledgement of saturated phenomena is an indicator that phenomenology can free itself from the prison of transcendentality, and that phenomena can give themselves »in themselves « beyond the conditions of possibility posed to them by the intentional subject. This requires a new understanding of the phenomenological reduction. In the version of Husserl or Heidegger the purpose of the reduction is to overcome naïve realism and bring phenomena back to the constitution of their givenness within intentional consciousness (or the constitution of beings, Seiende, within the prior understanding of Being, Sein). For Marion, the reduction is not about coming back to the subject pole, but the inverse: it leads to the original and undistorted givenness of phenomena, as and inasmuch as they give themselves in and from themselves (we cannot say the sobject pole», because the notion of »objectness" is already a problematic consequence of Husserl's transcendental reduction).

By changing the presuppositions of Husserl's phenomenology, Marion has to introduce a distinction between the phenomenon as (transcendentally) constituted by intentional acts (on the part of the subject) and the phenomenon in itself. He must grant the phenomenon its own »self « (Marion 2002a, 248), which is prior to its phenomenalization, or the appearing of the phenomenon with the aid of the subject. Here we are not dealing with the Kantian distinction between the phenomenon and the thing in itself, because there is no ontological reality outside the phenomenon. Nevertheless, without admitting this "self « to the pheno- 
menon, the notion of the self-givenness of phenomena would no longer have any meaning at all. If we take for example the phenomenon of the face, which belongs to the icon-type of saturated phenomena, the intentional subject has to acknowledge a specific "self « to the face, which is the initiator of givenness and which transcends any attempt to contain (to grasp) it within the limits of the subject's intentionality. The phenomenological reduction, as Marion interprets it, does not lead to the constitution of the meaning of the face by the intentional subject, but to the self-givenness of the face beyond the boundaries of intentionality.

This reversal of the phenomenological reduction has far-reaching methodological consequences. It could be regarded as a methodological turn within phenomenology itself. Marion (7) uses expressions like »counter-method", »counter-intentionality«, or even »counter-experience« $(2008,138)$. Levinas' unique experience in front of the face now becomes a universal paradigm for the relation of the subject toward phenomenal reality. This then inevitably leads to a new status of the subject or "what comes after the subject" $(2002 a, 249)$. The subject is the addressee of phenomena which give themselves according to their own initiative. There are some similarities between Levinas' subject »in accusative« and Marion's subject »in dative" (I'adonné, the gifted, the devoted). However, whereas Levinas insists on the radical passivity of the subject, Marion retains some active aspects of the adonné "who is himself received from what gives itself" (282). It is true that the adonné does not exist prior to the reception of givenness - in that sense he is always posterior to givenness - but, unlike the absolutely passive subject by Levinas, he must receive or assume himself. Marion rejects the criticism that he tolerates a phenomenological »experience without a subject» $(2008,123)$, as his overall objective is to think of subjectivity in a non-ontological and non-transcendental manner. Everything that the adonné »is« has been given to him, but this also includes what we can call his "active powers". The adonné's original status of passivity does not negate his ability to respond to the givenness in an active way (143). It does not preclude or diminish his freedom: his ability to will and to decide $(2012,141)$.

But, is Marion's position really tenable? Is it possible to substitute the phenomenological method with a counter-method, and then to transform its exceptional status (as does Levinas) into a new norm and a new normality? Could not have Marion merely fallen prey to a new form of naiveté? From which position does he speak when he assumes the self of phenomena, and describes their self-giving before and beyond the subject? How can we talk about intuitions overflowing intentions if we cannot but think intentionally (or conceptually), even when experiencing an intuition? How then is it possible to speak about the deposition of the transcendental subject if it seems to accompany and to make every kind of speaking and thinking possible? In my opinion, there is no logical necessity to perform Marion's phenomenological turn and accept the inversion of intentionality (the counter-method). But it is a possibility, and no less rationally justified than the classical phenomenology of Husserl or Heidegger. Marion's inversion implies some kind of »conversion«: there must be a »decision to see« (Carlson 2007) differen- 
tly, to transcend not only the natural, but even the phenomenological attitude of Husserl. This »post-transcendental« attitude includes a specific acknowledgment: the priority of otherness or givenness over the transcendental I (ego) - even if this acknowledgement has to be performed by the I itself.

\section{Decision and acknowledgement}

In his lectures titled The Idea of Phenomenology (1907), Husserl writes that the phenomenological reduction "excludes everything that is posited as transcendent (Husserl 1999, 63). In this immanence of intentional consciousness, however, he introduces the notion of "reelle Immanenz" which is not to be equated with the (empirical) real presence, but also is not something purely ideal. What is immanent in this way "counts as indubitable precisely because it presents nothing else, it refers to nothing sbeyond itself, because here what is meant is also adequately self-given, full and complete« (63). This absolute givenness as a complete intuitive fulfilment of intention must, however, be acknowledged as such. One might say that this is a trivial claim, because what motivates Husserl is the possibility of the (objective) knowledge of reality, which according to the most basic experience is something other than me (the I) and my consciousness. $\mathrm{Ne}$ vertheless, if the perfect phenomenological situation is one of immanence (excluding all transcendence), one could ask the question - as Levinas later does - of whether a phenomenon in its self-givenness is really something other than consciousness. ${ }^{2}$ It is not contradictory (at least in theoretical terms) to adopt a solipsist position (mentioned by (17), or to say along with Fichte that it is the I who posits the non-I. The consciousness has to acknowledge the intuitive givenness of phenomena as their self-givenness. If I see the color red (my intention or concept of »red « is fulfilled by a concrete and full intuition), I acknowledge it as a phenomenon in its own right, in its own sovereignty.

It is already at this level that the subject is called to decide and to acknowledge the otherness within the immanence of the phenomenological reduction, and, precisely since there is a situation of immanence, this decision to acknowledge could also be different. After these lectures, Husserl decided to embrace the transcendental approach which he fully developed in his Ideen, whereas Marion - who commented on these lectures of Husserl in depth (Marion 2011, 28) - insists on the inverse way of moving from the transcendental role of consciousness towards the self-givenness of phenomena. But, the ambiguity of the original phenomenological situation remains: it is the decision of the subject whether or not to admit and acknowledge otherness (and transcendence), or to remain closed within its own immanence.

2 Husserl $(1999,41)$ distinguishes within this immanence between what is »reell« and what is (purely) intentional: "And here we will not only be concerned with what is really [reell] immanent, but also with what is immanent in the intentional sense. It belongs to the essence of cognitive experiences to have an intentio: they refer to something; they relate themselves in one way or another to an objectivity." 
Even if Marion wants to present a compelling description of what he calls saturated phenomena - and he does this in a remarkable manner - there is still a need for the voluntary decision to acknowledge them as such. Marion's understanding of phenomenology demands far more than an abstract theoretical stance: it is ultimately about the acknowledgement, about my acknowledgment that everything that is « is given; that what we call reality is in fact a saturated phenomenality that cannot be subdued to our limitations, and that I myself am a saturated phenomenon (which is another way of expressing the traditional idea of creation, or perhaps better, createdness), because I acknowledge and recognize myself as being given to myself. ${ }^{3}$ There could also be a different, i.e. a transcendental way, which would conclude (or deduce) the necessity of the transcendental I beneath the empirical I. Kant argues that the subject must recognize the transcendental role of $» \mid$ think $"{ }^{4}$ which accompanies every representation, or every content of thinking. But this deduction which posits the necessity of the transcendental unity of self-consciousness is a pure act of thinking without any intuitive givenness. What is more convincing: to believe in the (necessity of the) transcendental I, or to believe that the "I « is always late with regard to it and thus given to it (even when it performs the transcendental deduction)?

The decision cannot be a blind choice. It must be a rational deliberation. It is important to emphasize the rationality of the counter-method. The paradox, which accompanies it, should not be excluded from rationality, but rather included in it. Levinas criticizes the domination of the traditional (onto)logical meaning and rationality (taken for granted), and pleads for an entirely different "structure« of meaning (the-One-for-the-Other); for an ethical rationality. With Marion (2008, 148) we could argue for a »higher reason " which is able to admit and attest to the priority of transcendence over correlative and adequate thinking. With higher reason it is possible to acknowledge a saturated phenomenon. At the same time, this acknowledgment also represents the primordial act of the self-transcendence of the adonné. Not that the adonné goes beyond himself by his own initiative. This is just a re-sponse which re-cognizes (acknowledges) the priority of the givenness which has always already (passé absolu) been given to the adonné.

Saturated phenomena are not rare occurrences within phenomenal reality. In

3 Could the term "acknowledgement « be substituted with the term »recognition «? Marion writes about this kind of recognition, or what I call acknowledgement, at the end of Reduction and Givenness, where he uses the term "interloqué« to characterize the subject: "I recognize myself as interloqué well before having consciousness or knowledge not only of my eventual subjectivity, but especially of what leaves me interloqué. /.../ This a priori [of a claim, BK] exerts itself all the more insofar as it is not identified, since it consists only in its pure recognition by the interloqué. The claim itself is attested in the recognition by the interloqué that it incurs a claim." (Marion 1998, 202) However, the problem with the term recognition is that it may be burdened with an extensive philosophical history, ranging from Hegel to contemporary thinkers like Honneth or Riceour. The notion of recognition is normally associated with (dialectical) reciprocity, symmetry, and mutuality, but this is precisely what is not meant with our interpretation of acknowledgement as an asymmetrical and non-reciprocal relationship.

4 Critique of Pure Reason, B 131-132: "The I think must be able to accompany all the representations; for otherwise something would be represented in me that could not be thought at all, which is as much as to say that the representation would either be impossible or else at least would be nothing for me." (Kant 1998, 246) 
the development of his thought, Marion extended the notion of saturated phenomena to almost all phenomenality, and he even speaks about their banality: "The banality of the saturated phenomenon suggests that the majority of phenomena, if not all can undergo saturation by the excess of intuition over the concept or signification in them « (126). This acknowledgement, therefore, does not only relate to some exceptional phenomena (Alvis 2018, 45), but to the whole of reality. Everything that »is ( (being, existence) has to acknowledge its origin in givenness. In this way a new kind of "ontology « becomes possible; an ontology posterior to givenness. To understand beings (Seiende) in their Being (Sein), as Heidegger would require it, presupposes an acknowledgement of givenness: it is given to the adonné in order for him to understand what gives itself (a phenomenon) as being, as existing. Ontology is related and, in this sense, relative to the recipient, to the adonné (whom Heidegger calls Dasein). Givenness, in contrast, is not relative, because it is prior and unconditional. For Marion, it becomes the first principle and it grants phenomenology the status of "first philosophy «. ${ }^{5}$ It also leads to the reversal of ontology: our understanding of being (ontology) is a response which includes the acknowledgement of an all-encompassing "giving" prior to and beyond ontology.

To acknowledge the priority of givenness leads to a kind of a Copernican reversal. Before the reversal the (transcendental) subject forms the center of reality: everything besides the subject, all of reality surrounding it, appears to be secondary and posterior. After the reversal there is the priority of "reality " - understood as everything that gives itself - over the subject. When the subject becomes conscious of itself (when it comes into »being "), it has to admit (to acknowledge) its secondary role: to be the recipient of the givenness, which is primary, and which always transcends its receptive capacities. The transcendence of givenness is prior to the immanence of the subject.

\section{The Copernican reversal and its consequences for theology}

It is clear that Marion's new phenomenological setting offers a favorable ground for a dialogue with theology, which is based on the phenomenon of revelation. Additionally, Marion seems to offer to Christian theology a new philosophical interpretation of reality which can be a substitute for traditional metaphysics, now widely discredited. This may even be the main objective of Marion's philosophical work, but this fact cannot be an argument to accuse him of having a hidden theological agenda.

5 "I thus conclude that no appearing is excepted from the fold of givenness, even if it does not always accomplish the phenomenal unfolding in it entirely. Givenness is never suspended, even if and precisely because it admits an indefiniteness of degrees. Yet again, there can be indefinite degrees of givenness but no exception from it. Givenness is thus set up, by its certitude and its automatic universality, in principle unconditioned. There could, therefore, be a sfirst philosophy according to phenomenology." (Marion 2002b, 23) 
Marion's Copernican reversal completely refigures the question about transcendence, which is usually associated with God, and is of central importance to every religion. We no longer have the problem of how - or if at all - we can reach transcendence, because the saturated phenomenal reality that surrounds us is "counter-experienced « as a constant givenness of transcendence. The question is rather whether such givenness which can be deemed divine revelation can actually occur. Such a revelation would still need to phenomenalize itself, to become a phenomenon, but it is not something that philosophy or phenomenology could anticipate or determine in advance. Philosophy cannot preclude revelation. To put it positively: it must allow for revelation as a possibility - not in the sense of "potency», which is set out to materialize itself in an »actus", but as a preclusion of impossibility, or in Marion's terms: the impossibility of impossibility (Marion $2015,69)$. Theology, in contrast, regards revelation as historically actualized, as an actuality which is accepted or sacknowledged « in the attitude of faith. Herein lies the main methodological difference between philosophy and theology.

Theology always presupposes some (philosophical) understanding of reality, irrespective of whether these ontological presuppositions are hidden and not reflected, or if they are thought of and thematized. In the Catholic tradition there has always been a need to combine (supernatural) revelation with a philosophical (or natural) understanding of reality. This is in contrast to the Protestant position, which is distrustful of any natural reason (which has been corrupted by original $\sin$ ) prior to or independent of revelation (it is not until we embrace faith that reason can be liberated from its fallenness and function properly). According to Karl Barth there can be no natural knowledge of God (i.e. natural or philosophical theology) prior to His revelation: in the revelation God "gives" Himself from Himself and according to Himself - without any prior (transcendental) conditions and irrespective of any »natural« reason. Marion has occasionally been reproached for appropriating the Barthian paradigm (Marion 2016, 57), which led to the criticism both from philosophy (for secretly transposing theology into phenomenology) and from Catholic theology (for his refusal of the classical metaphysics of being). But Marion offers a differentiated position which escapes both criticisms. His phenomenological analyses are based on rational argumentation. However, in the philosophical search for truth there are moments of decision regarding what is acknowledged as prior and principal. This may point to an inevitable element of faith (in a general sense) within philosophical reasoning, which is related to human freedom. But any such decision or acknowledgment seeks to find a rational justification (sometimes expanding on the notion of rationality), and it is able to enter into a rational discussion with competing positions.

The second criticism concerning Marion's refusal of the metaphysics of being, which is still an important philosophical reference for Catholic thinking, can be dismissed in a similar way. Despite its apparent resemblance to the Barthian position, Marion develops a philosophically autonomous - we could even say a natural - account of reality. He could accept the scholastic distinction between natural reason and supernatural revelation, where supernatural grace does not »de- 
stroy nature, but fulfils it «. However, he rejects the position that natural reason has to be identified with the (onto)logical thinking of classical metaphysics (no longer regarded as philosophia perennis, but as a historically contingent vein of thought). Marion shares Heidegger's criticism of metaphysics, which has been accused of a specific attitude towards reality: an attitude of power and domination. It is the same attitude that we find in the transcendental approach, which Marion tries to overcome with his phenomenology of givenness, and which also implies a reversal in attitude: the approach of domination is replaced with one of humility when faced with saturated phenomenality.

Although Marion's phenomenology of givenness dismisses the priority of ontology - either in the form of classical metaphysics or in the form of Heidegger's thinking of Being - he does not reject the question of »being " altogether. But this question becomes of secondary importance, as it always presupposes the primacy and anteriority of givenness. It is the adonné who brings being to language (who announces what »is «), but this articulation is a never-ending response (a hermeneutic "without end ", Marion 2002b, 33) to what gives itself prior to and beyond being. There is no possibility for the adonné to go beyond givenness - to pose and propose some ontological giver behind the givenness, which would repeat the ontotheological gesture of proving God's existence. Marion also refuses the method of analogy, not only in the ontological sense (analogia entis), but in general. To think of transcendence "according to the same logos" (ana ton auton logon, i.e. analogically), which we encounter within our immanence, is always susceptible to idolatry. The only way to know something about transcendence is through its own givenness, through its own revelation. However, as already mentioned, this does not diminish the role of philosophy for theology. The acknowledgment of saturated phenomenality is a "natural « experience of transcendence. The grace of God's revelation builds upon and perfects this natural experience (gratia praesupponit et perficit naturam).

There is a remarkable statement made by Marion in his conversation with Dan Arbib, which can help us understand his view of both phenomenology and theology. It shows how the Copernican reversal lies at the very center of his thinking and how it is related to a fundamental »acknowledgement«:

"Then came the day when I finally discovered that the crucial problem lies not in knowing or not knowing the existence of God, but in figuring out whether I myself am sure about my own existence. For let's be serious: existence is the least thing we could dispute of God. The question would rather be whether anything that is not God could ever hope to be? /.../ There is nothing exterior, absolutely nothing that is not found already and above all given a norm by God, including the questions of his being and his potential existence. /.../ The idea that there is anything outside of God has no meaning at all. That was for me truly a Copernican reversal, one about which I have never had the slightest doubt." $(2017,28)$ 
This passage may be perceived as an argument for those who reproach Marion for pursuing a theological agenda in his philosophical thinking. I would rather interpret it as an impulse regarding Marion's new phenomenological approach to reality and his search for a phenomenological Copernican turn: a turn away from the self-centeredness of the subject toward the radical priority of transcendent givenness. It is a turn which again seeks to reverse Kant's famous Copernican turn without falling back to the old metaphysics. But, it is as paradoxical as the possibility of experiencing saturated phenomena; that is, if we acknowledge them at all in the first place.

\section{References}

Alvis, Jason. 2018. The Inconspicuous God: Heidegger, French Phenomenology, and the Theological Turn. Bloomington, IN: Indiana University Press.

Carlson, Thomas A. 2007. Blindness and the Decision to See. On Revelation and Reception in Jean-Luc Marion. In: Kevin Hart, ed. Counter-Experiences: Reading Jean-Luc Marion, 153179. Notre Dame (IN): University of Notre Dame Press.

Esterbauer, Reinhold. 2013. Zeit als »geduldiges Warten auf Gott«: Zur Konzeption von Transzendenz in »Totalité et Infini«. In: Norbert Fischer and Jakub Sirovátka, eds. Die Gottesfrage in der Philosophie von Emmanuel Levinas, 159-185. Hamburg: Meiner.

Husserl, Edmund. 1999. The Idea of Phenomenology. Translated by Lee Hardy. Dordrecht: Kluwer.

Janicaud, Dominique. 2000. The Theological Turn of French Phenomenology. In: Phenomenology and the "Theological Turn", 16-103. Ed. Dominique Janicaud. New York: Fordham University Press.

Kant, Immanuel. 1998. Critique of Pure Reason. Translated by Paul Guyer and Allan Wood. Cambridge: Cambridge University Press.

Klun, Branko. 2012. L'ontologie est-elle totalitaire? Une relecture critique de Levinas. Revue philosophique de Louvain 110, no. 4:659-683.

Levinas, Emmanuel. 1969. Totality and Infinity: An Essay on Exteriority. Translated by Alphonso Lingis. The Hague: Nijhoff.

- - - 1991. Otherwise Than Being Or Beyond Essence. Translated by Alphonso Lingis, Dordrecht: Kluwer.

- - - 1994. La trace de l'autre. In: En découvrant l'existence avec Husserl et Heidegger. Paris: Vrin.
Marion, Jean-Luc. 1998. Reduction and Givenness: Investigations of Husserl, Heidegger, and Phenomenology. Translated by Thomas A. Carlson. Evanston: Northwestern University Press.

- - . 2002a. Being Given: Toward a Phenomenology of Givenness. Stanford: Stanford University Press.

- - . 2002b. In Excess: Studies of Saturated Phenomena. Translated by Robyn Horner and Vincent Berraud. New York: Fordham University Press.

- - . 2008. The Visible and the Revealed. Translated by Christina M. Gschwandtner. New York: Fordham University Press.

- - - 2011. The Reason of the Gift. Translated by Stephen E. Lewis. Charlottesville \& London: Virginia University Press.

- - - 2015. Negative Certainties. Translated by Stephen E. Lewis. Chicago: University of Chicago Press.

---. 2016. Givenness and Revelation. Translated by Stephen E. Lewis. Oxford: Oxford University Press.

- - . 2017. The Rigor of Things: Conversations with Dan Arbib. Translated by Christina M. Gschwandtner. New York: Fordham University Press.

Mensch, James. 2017. Transcendence and Intertwining. Bogoslovni vestnik [Theological Quarterly] 77, no. 3/4:477-487.

Welten, Ruud. 2004. Saturation and Disappointment: Marion according to Husserl. Bijdragen: International Journal in Philosophy and Theology 65, no. 1:79-96. https://doi.org/10.2143/ bij.65.1.503907 